\title{
Marinicola seohaensis gen. nov., sp. nov., isolated from sea water of the Yellow Sea, Korea
}

\author{
Jung-Hoon Yoon, So-Jung Kang, Choong-Hwan Lee and Tae-Kwang Oh \\ Korea Research Institute of Bioscience and Biotechnology (KRIBB), PO Box 115, Yusong, \\ Taejon, Korea
}

Correspondence

Jung-Hoon Yoon

jhyoon@kribb.re.kr

\begin{abstract}
A Gram-negative, non-flagellated, non-spore-forming and rod-shaped bacterial strain, SW $-152^{\top}$, was isolated from sea water of the Yellow Sea in Korea, and subjected to a polyphasic taxonomic study. Strain $\mathrm{SW}-152^{\top}$ grew optimally at $30^{\circ} \mathrm{C}$ and in the presence of $2-3 \%(\mathrm{w} / \mathrm{v}) \mathrm{NaCl}$. It contained $\mathrm{MK}-7$ as the predominant menaquinone and iso- $\mathrm{C}_{15: 0}$ and iso- $\mathrm{C}_{15: 1}$ as the major fatty acids. Polar lipids detected in strain $\mathrm{SW}-152^{\top}$ were phosphatidylethanolamine, diphosphatidylglycerol and unidentified lipids. The DNA G+C content was $40 \cdot 3$ mol\%. Phylogenetic trees based on 16S rRNA gene sequences exhibited that strain $S W-152^{\top}$ forms a distinct evolutionary lineage within the Cytophaga-FlavobacteriumBacteroides (CFB) group. Strain SW $-152^{\top}$ exhibited low $16 \mathrm{~S}$ rRNA similarity levels of less than $89.4 \%$ to members belonging to the CFB group. Phenotypic properties of strain SW-152 differentiate it from phylogenetically related taxa. On the basis of phenotypic and phylogenetic data, strain SW-152 ${ }^{\top}$ (=KCTC $\left.12312^{\top}=\mathrm{JCM} 12600^{\top}\right)$ was classified in a novel genus and species, Marinicola seohaensis gen. nov., sp. nov.
\end{abstract}

Members of the Cytophaga-Flavobacterium-Bacteroides (CFB) group are widely distributed in nature, particularly marine environments (Glöckner et al., 1999; Kirchman, 2002). The CFB group has been known to play an important role in carbon cycling in the marine environments (Kirchman, 2002). However, the taxonomy of the CFB group has been confused, and phylogenetic differentiation of some members belonging to the CFB group is still not clear-cut (Suzuki et al., 2001; Bernardet et al., 2002). Taxonomic re-evaluations and reclassifications of many taxa belonging to the CFB group have been performed recently (Nakagawa \& Yamasato, 1996; Bernardet et al., 1996; Johansen et al., 1999; McCammon \& Bowman, 2000; Barbeyron et al., 2001; Suzuki et al., 2001; Sakamoto et al., 2002). During the last few years, developments in bacterial systematics have increased continuously the number of novel taxa assigned to the CFB group (Bowman et al., 2003). In this study, we describe a slightly halophilic bacterial strain, $S W-152^{\mathrm{T}}$, which was isolated from sea water in the Yellow Sea, Korea. The result of a 16S rRNA gene sequence comparison indicated that the strain should be considered to be a member of the CFB group. The aim of the present work was to determine the exact taxonomic

Published online ahead of print on 5 November 2004 as DOI 10.1099/ ijs.0.63492-0.

Abbreviation: CFB, Cytophaga-Flavobacterium-Bacteroides.

The GenBank/EMBL/DDBJ accession number for the 16S rRNA gene sequence of strain SW-152 ${ }^{\top}$ is AY739663. position of strain $\mathrm{SW}-152^{\mathrm{T}}$ by a polyphasic taxonomic characterization.

Sea water collected from the Yellow Sea, Korea, was used as the source for isolation of bacterial strains. Strain SW- $152^{\mathrm{T}}$ was isolated by the standard dilution plating technique at $25^{\circ} \mathrm{C}$ on marine agar 2216 (MA; Difco). To investigate its morphological characteristics, strain $\mathrm{SW}-152^{\mathrm{T}}$ was routinely cultivated at $30{ }^{\circ} \mathrm{C}$ on MA. Cell morphology was examined by light microscopy (Nikon E600) and transmission electron microscopy (TEM). The presence of flagella was examined by TEM using cells from exponentially growing cultures. Gliding motility was determined as described by Bowman (2000). Gram reaction was determined using the bioMérieux Gram Stain kit according to the manufacturer's instructions. Growth at various temperatures $\left(4-45^{\circ} \mathrm{C}\right)$ was measured on MA. The $\mathrm{pH}$ range for growth was determined in marine broth 2216 (MB; Difco) that was adjusted to various $\mathrm{pH}$ values $(\mathrm{pH} 4 \cdot 5-10 \cdot 0$ at intervals of $0.5 \mathrm{pH}$ units). Growth under anaerobic conditions was determined after incubation in a Forma anaerobic chamber on MA and MA supplemented with nitrate, both of which had been prepared anaerobically using nitrogen. Catalase and oxidase activities and hydrolysis of casein, starch and Tweens 20, 40, 60 and 80 were determined as described by Cowan \& Steel (1965). Hydrolysis of hypoxanthine, tyrosine and xanthine was tested on MA using the substrate concentrations described by Cowan \& Steel (1965). Hydrolysis of aesculin, gelatin and urea and 
nitrate reduction were studied as described previously (Lanyi, 1987) with the modification that artificial sea water was used for preparation of media. The artificial sea water contained (per litre of distilled water) $23.6 \mathrm{~g} \mathrm{NaCl}, 0.64 \mathrm{~g}$ $\mathrm{KCl}, 4.53 \mathrm{~g} \mathrm{MgCl}_{2} \cdot 6 \mathrm{H}_{2} \mathrm{O}, 5.94 \mathrm{~g} \mathrm{MgSO}_{4} \cdot 7 \mathrm{H}_{2} \mathrm{O}$ and $1.3 \mathrm{~g}$ $\mathrm{CaCl}_{2} \cdot 2 \mathrm{H}_{2} \mathrm{O}$ (Bruns et al., 2001). $\mathrm{H}_{2} \mathrm{~S}$ production was tested as described previously (Bruns et al., 2001). Presence of flexirubin pigment was investigated as described by Reichenbach (1992). Acid production from carbohydrates was determined as described by Leifson (1963). Growth on several substrates was tested in a basal medium containing $0.2 \mathrm{~g} \mathrm{NaNO}_{3}, 0.2 \mathrm{~g} \mathrm{NH}_{4} \mathrm{Cl}$ and $0.05 \mathrm{~g}$ yeast extract in 1 litre artificial sea water (Bruns et al., 2001) as described by Suzuki et al. (2001). Susceptibility to antibiotics was determined on MA plates by using antibiotic discs with the following concentrations: penicillin $\mathrm{G}(20 \mathrm{U})$, carbenicillin $(100 \mu \mathrm{g})$, gentamicin $(10 \mu \mathrm{g})$, kanamycin $(30 \mu \mathrm{g})$, lincomycin $(15 \mu \mathrm{g})$, neomycin $(30 \mu \mathrm{g})$, polymyxin B (300 $\mathrm{U})$, streptomycin $(10 \mu \mathrm{g})$, tetracycline $(30 \mu \mathrm{g})$, ampicillin $(10 \mu \mathrm{g})$, oleandomycin $(15 \mu \mathrm{g})$ and chloramphenicol $(100 \mu \mathrm{g})$. Other physiological tests were performed with the API 20E system (bioMérieux).

Cell biomass for isoprenoid quinone and polar lipid analyses and for DNA extraction was obtained after cultivation for 3 days in $\mathrm{MB}$ at $30^{\circ} \mathrm{C}$. Isoprenoid quinones were analysed as described by Komagata \& Suzuki (1987) using reversed-phase HPLC. Chromosomal DNA isolation and purification were performed according to the method described by Yoon et al. (1996), with the exception that ribonuclease $\mathrm{T} 1$ was treated in combination with ribonuclease $\mathrm{A}$ to minimize the contamination of RNA. For fatty acid methyl ester (FAME) analysis, a loop of cell mass was harvested from agar plates after incubation for 3 days on MA at $30^{\circ} \mathrm{C}$. The FAMEs were extracted and prepared according to the standard protocol of the MIDI/Hewlett Packard Microbial Identification System (Sasser, 1990). The DNA G + C content was determined by the method of Tamaoka \& Komagata (1984) with the modification that DNA was hydrolysed and the resultant nucleotides were analysed by reversed-phase HPLC.

The 16S rRNA gene was amplified by PCR using two universal primers as described previously (Yoon et al., 1998). Sequencing of the amplified 16S rRNA gene was performed as described by Yoon et al. (2003). Alignment of sequences was carried out with CLUSTAL W software (Thompson et al., 1994). Gaps at the $5^{\prime}$ and $3^{\prime}$ ends of the alignment were omitted from further analyses. Phylogenetic trees were inferred by using three tree-making algorithms, the neighbour-joining (Saitou \& Nei, 1987), maximumlikelihood (Felsenstein, 1981) and maximum-parsimony (Kluge \& Farris, 1969) methods implemented within the PHYLIP package (Felsenstein, 1993). Evolutionary distance matrices for the neighbour-joining method were calculated by the algorithm of Jukes \& Cantor (1969) using the program DNADIST. The stability of relationships was assessed by a bootstrap analysis based on 1000 resamplings of the neighbour-joining dataset by using the programs SEQBOOT, DNADIST, NEIGHBOR and CONSENSE of the PHYLIP package.

Morphological, cultural, physiological and biochemical characteristics of strain $\mathrm{SW}-152^{\mathrm{T}}$ are shown in Table 1 or given in the genus and species descriptions (see below). Strain SW-152 ${ }^{\mathrm{T}}$ contained menaquinone-7 (MK-7) as the predominant isoprenoid quinone at peak area ratio of approximately $91 \%$. Strain SW- $152^{\mathrm{T}}$ had a fatty acid profile that contained large amounts of iso-branched- and hydroxy fatty acids. The major fatty acid components $(>1 \%)$ detected in strain $\mathrm{SW}-152^{\mathrm{T}}$ were as follows: iso$\mathrm{C}_{15: 0}(33.5 \%)$, iso- $\mathrm{C}_{15: 1}(20 \cdot 5 \%)$, iso- $\mathrm{C}_{17: 0} 3-\mathrm{OH}(11 \cdot 2 \%)$, iso- $\mathrm{C}_{16: 0} 3-\mathrm{OH}(7 \cdot 2 \%)$, iso- $\mathrm{C}_{15: 0} 3-\mathrm{OH}(5 \cdot 6 \%)$, iso- $\mathrm{C}_{13: 0}$ $(5 \cdot 2 \%)$, iso- $\mathrm{C}_{15: 0} 2-\mathrm{OH}$ and/or $\mathrm{C}_{16: 1} \omega 7 c(4 \cdot 8 \%)$, anteiso$\mathrm{C}_{15: 0}(2 \cdot 4 \%), \mathrm{C}_{16: 0} 3-\mathrm{OH}(1 \cdot 8 \%)$, iso- $\mathrm{C}_{16: 0}(1 \cdot 2 \%)$ and $\mathrm{C}_{15: 0}(1 \cdot 1 \%)$. Polar lipids detected in strain $\mathrm{SW}-152^{\mathrm{T}}$ were phosphatidylethanolamine, diphosphatidylglycerol, an unidentified glycolipid and an unidentified phospholipid. An amino-group-containing lipid that was ninhydrinpositive was also detected. The DNA $\mathrm{G}+\mathrm{C}$ content of strain SW- $152^{\mathrm{T}}$ was $40 \cdot 3 \mathrm{~mol} \%$.

An almost-complete 16S rRNA gene sequence of strain $\mathrm{SW}-152^{\mathrm{T}}$ determined in this study comprised $1472 \mathrm{nt}$. Sequence searches with public databases revealed that the $16 \mathrm{~S}$ rRNA gene sequence of strain $\mathrm{SW}-152^{\mathrm{T}}$ shows highest sequence similarity to those of the CFB group. In the neighbour-joining phylogenetic tree based on 16S rRNA gene sequences, strain $\mathrm{SW}-152^{\mathrm{T}}$ formed an independent phylogenetic lineage within the evolutionary radiation enclosed by members of the CFB group (Fig. 1). Strain SW- $-152^{\mathrm{T}}$ exhibited $16 \mathrm{~S}$ rRNA gene sequence similarity levels of less than $89 \cdot 4 \%$ to all species used in the phylogenetic analysis (Fig. 1).

The phylogenetic analyses based on 16S rRNA gene sequences indicated that strain $\mathrm{SW}-152^{\mathrm{T}}$ does not fall within the radiation encompassed by a recognized genus but forms a distinct evolutionary lineage within the CFB group. Although strain SW-152 ${ }^{\mathrm{T}}$ joined Reichenbachia agariperforans by a bootstrap resampling value of $69 \cdot 3 \%$ and these two formed a cluster with Persicobacter diffluens and [Flexibacter] aggregans, $16 \mathrm{~S}$ rRNA gene sequence similarity values between strain $\mathrm{SW}-152^{\mathrm{T}}$ and the three species were very low $(<89 \cdot 4 \%)$. Strain $\mathrm{SW}-152^{\mathrm{T}}$ is differentiated from several phylogenetically related taxa by some phenotypic characteristics as shown in Table 1. Accordingly, it is appropriate that strain $\mathrm{SW}-152^{\mathrm{T}}$ be allocated in a new genus within the CFB group. On the basis of the phenotypic and phylogenetic data, we propose the creation of a novel genus and species, Marinicola seohaensis gen. nov., sp. nov., for strain SW- $152^{\mathrm{T}}$.

\section{Description of Marinicola gen. nov.}

Marinicola (Ma.ri.ni'co.la. L. adj. marinus of the sea; L. masc. suffix -cola inhabitant; N.L. masc. n. Marinicola inhabitant of the sea). 
Table 1. Differential phenotypic characteristics of strain $S W-152^{\top}$ and some related taxa

Taxa: 1, strain SW-152 ${ }^{\mathrm{T}}$; 2, genus Reichenbachia; 3, genus Persicobacter; 4, [Flexibacter] aggregans. Data from this study, Reichenbach (1989), Nakagawa et al. (1997), Bowman et al. (2003) and Nedashkovskaya et al. (2003). +, Positive; -, negative; ND, not determined. Data in parentheses are for type strains. All taxa are Gram-negative, strictly aerobic, rod-shaped, motile by means of gliding, oxidase-positive, negative for casein hydrolysis and require $\mathrm{Na}^{+}$or sea water for growth.

\begin{tabular}{|c|c|c|c|c|}
\hline Characteristic & 1 & 2 & 3 & 4 \\
\hline Catalase & + & + & - & + \\
\hline Optimal growth temperature $\left({ }^{\circ} \mathrm{C}\right)$ & 30 & $25-28$ & $25-30$ & $\mathrm{ND}$ \\
\hline Maximum growth temperature $\left({ }^{\circ} \mathrm{C}\right)$ & 40 & 35 & $<45$ & $35-45$ \\
\hline Growth at $4{ }^{\circ} \mathrm{C}$ & + & + & - & - \\
\hline Carbohydrate utilization & - & - & + & + \\
\hline \multicolumn{5}{|l|}{ Hydrolysis of: } \\
\hline Agar & - & + & + & + \\
\hline Gelatin & - & + & + & - \\
\hline Starch & - & + & + & - \\
\hline
\end{tabular}

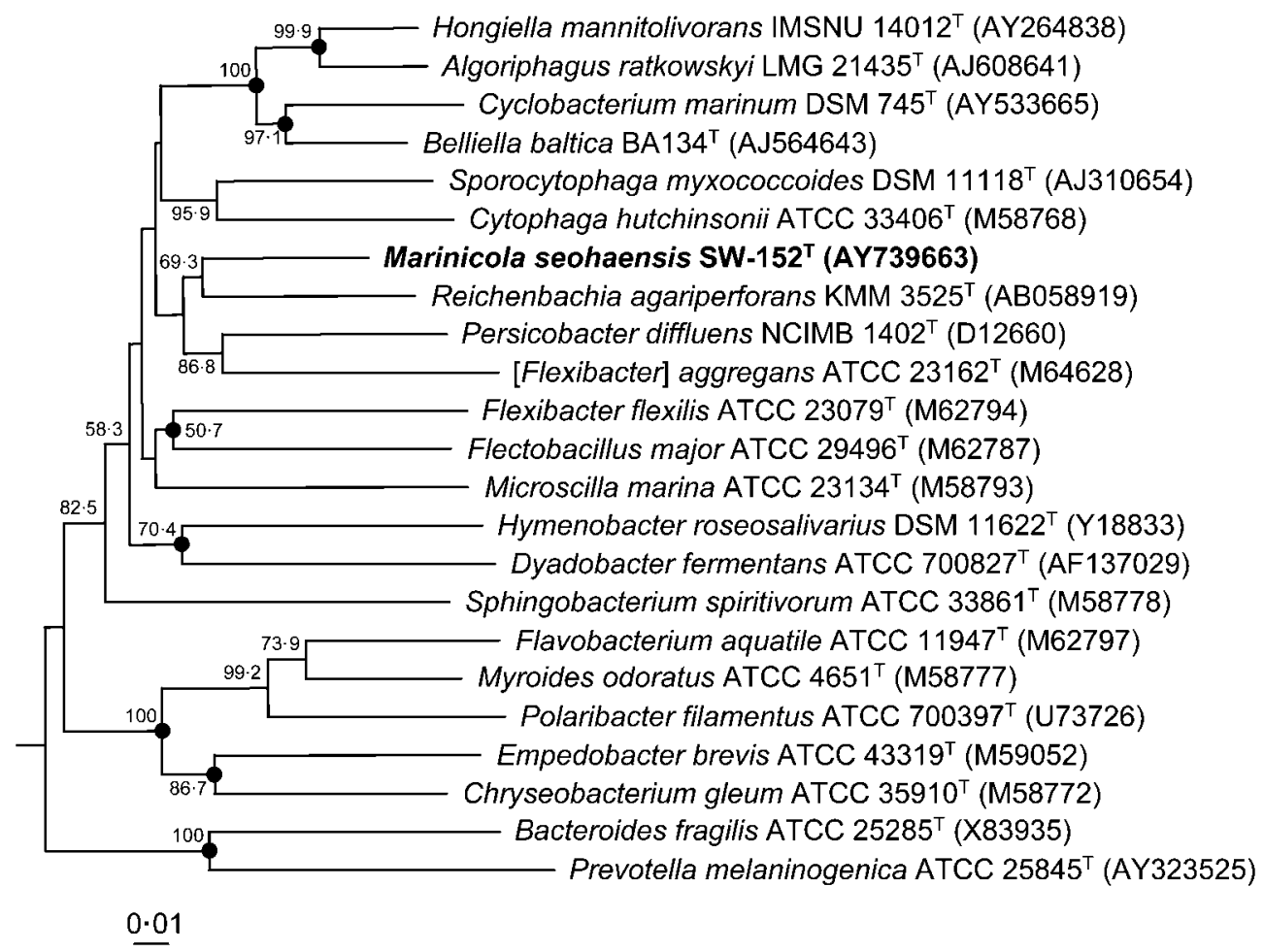

Fig. 1. Neighbour-joining phylogenetic tree based on $16 \mathrm{~S}$ rRNA gene sequences showing the positions of strain $S W-152^{\top}$ and some other related taxa. The numbers on the branches indicate the bootstrap value of 1000 resamplings (greater than $50 \%$ ). Bar, 0.01 substitution per nucleotide position. Dots represent that the corresponding nodes are also recovered in the maximum-likelihood tree. Chlorobium limicola DSM $245^{\top}$ was used as an outgroup. 
Cells are Gram-negative, non-flagellated, non-spore-forming and rod-shaped. Strictly aerobic. Motile by means of gliding. Flexirubin pigment is produced. Catalase- and oxidasepositive. Predominant menaquinone is MK-7. Major fatty acids are iso- $\mathrm{C}_{15: 0}(33 \cdot 5 \%)$ and iso- $\mathrm{C}_{15: 1}(20 \cdot 5 \%)$. Major phospholipids are phosphatidylethanolamine and diphosphatidylglycerol. DNA G + C content is $40.3 \mathrm{~mol} \%$.

The type species is Marinicola seohaensis.

\section{Description of Marinicola seohaensis sp. nov.}

Marinicola seohaensis (seo.ha.en'sis. N.L. masc. adj. seohaensis of Seohae, the Korean name for the Yellow Sea in Korea, from where the organism was isolated).

Exhibits the following properties in addition to those given in the genus description. Cells are Gram-negative, strictly aerobic rods, $0 \cdot 2-0 \cdot 3 \times 2 \cdot 0-4 \cdot 0 \mu \mathrm{m}$. Colonies are circular, convex, glistening, smooth, strong orange in colour and 1-2 $\mathrm{mm}$ in diameter after incubation for 3 days on MA at $30{ }^{\circ} \mathrm{C}$. Growth occurs at 4 and $40^{\circ} \mathrm{C}$, with an optimum temperature of $30^{\circ} \mathrm{C}$; growth does not occur above $41^{\circ} \mathrm{C}$. Optimal growth occurs in the presence of $2-3 \%(\mathrm{w} / \mathrm{v})$ $\mathrm{NaCl}$; growth does not occur in the absence of $\mathrm{NaCl}$ and in the presence of greater than $9 \%(\mathrm{w} / \mathrm{v}) \mathrm{NaCl}$. Optimal $\mathrm{pH}$ for growth is between $7 \cdot 0$ and 8.0 ; growth is observed at $\mathrm{pH} 5 \cdot 5$, but not at $\mathrm{pH} 5 \cdot 0$. Urease-negative. Tweens 20,40 , 60 and 80 are weakly hydrolysed. Aesculin, hypoxanthine, xanthine and tyrosine are not hydrolysed. Nitrate is not reduced. $\mathrm{H}_{2} \mathrm{~S}$ and indole are not produced. Growth occurs on Casamino acids, peptone and tryptone as the sole carbon and nitrogen sources, but does not occur on D-glucose, sucrose, D-ribose, DL-aspartate, L-glutamic acid, L-leucine or L-proline. No acid is produced from L-arabinose, D-cellobiose, D-fructose, D-galactose, D-glucose, lactose, maltose, D-mannose, D-melezitose, melibiose, D-raffinose, L-rhamnose, D-ribose, sucrose, D-trehalose, D-xylose, adonitol, myo-inositol, D-mannitol or D-sorbitol. Arginine dihydrolase, lysine decarboxylase, ornithine decarboxylase and tryptophan deaminase are absent. When assayed with the API ZYM system, alkaline phosphatase, esterase lipase (C 8), leucine arylamidase, $\alpha$-chymotrypsin, acid phosphatase, naphthol-AS-BI-phosphohydrolase and $N$-acetyl- $\beta$ glucosaminidase are present and esterase (C 4) and valine arylamidase are weakly present, but lipase (C 14), cystine arylamidase, trypsin, $\alpha$-galactosidase, $\beta$-galactosidase, $\beta$ glucuronidase, $\alpha$-glucosidase, $\beta$-glucosidase, $\alpha$-mannosidase and $\alpha$-fucosidase are absent. Susceptible to carbenicillin, lincomycin, oleandomycin and chloramphenicol, but not to penicillin G, gentamicin, kanamycin, neomycin, polymyxin $\mathrm{B}$, streptomycin, tetracycline or ampicillin. Polar lipids are phosphatidylethanolamine, diphosphatidylglycerol, an unidentified glycolipid, an unidentified phospholipid and a ninhydrin-positive lipid. DNA G $+C$ content is $40 \cdot 3 \mathrm{~mol} \%$. Other phenotypic properties are given in Table 1.

The type strain, SW $-152^{\mathrm{T}}\left(=\right.$ KCTC $\left.12312^{\mathrm{T}}=\mathrm{JCM} 12600^{\mathrm{T}}\right)$, was isolated from sea water of the Yellow Sea, Korea.

\section{Acknowledgements}

This work was supported by the 21C Frontier program of Microbial Genomics and Applications (grant MG02-0401-001-1-0-0) from the Ministry of Science and Technology (MOST) of the Republic of Korea.

\section{References}

Barbeyron, T., L'Haridon, S., Corre, E., Kloareg, B. \& Potin, P. (2001). Zobellia galactanovorans gen. nov., sp. nov., a marine species of Flavobacteriaceae isolated from a red alga, and classification of [Cytophaga] uliginosa (ZoBell and Upham 1944) Reichenbach 1989 as Zobellia uliginosa gen. nov., comb. nov. Int J Syst Evol Microbiol 51, 985-997.

Bernardet, J.-F., Segers, P., Vancanneyt, M., Berthe, F., Kersters, K. \& Vandamme, P. (1996). Cutting a Gordian knot: emended classification and description of the genus Flavobacterium, emended description of the family Flavobacteriaceae, and proposal of Flavobacterium hydatis nom. nov. (basonym, Cytophaga aquatilis Strohl and Tait 1978). Int J Syst Bacteriol 46, 128-148.

Bernardet, J.-F., Nakagawa, Y. \& Holmes, B. (2002). Proposed minimal standards for describing new taxa of the family Flavobacteriaceae, and emended description of the family. Int J Syst Evol Microbiol 52, 1049-1070.

Bowman, J. P. (2000). Description of Cellulophaga algicola sp. nov., isolated from the surfaces of Antarctic algae, and reclassification of Cytophaga uliginosa (ZoBell and Upham 1944) Reichenbach 1989 as Cellulophaga uliginosa comb. nov. Int J Syst Evol Microbiol 50, 1861-1868.

Bowman, J. P., Nichols, C. M. \& Gibson, J. A. E. (2003). Algoriphagus ratkowskyi gen. nov., sp. nov., Brumimicrobium glaciale gen. nov., sp. nov., Cryomorpha ignava gen. nov., sp. nov. and Crocinitomix catalasitica gen. nov., sp. nov., novel flavobacteria isolated from various polar habitats. Int J Syst Evol Microbiol 53, 1343-1355.

Bruns, A., Rohde, M. \& Berthe-Corti, L. (2001). Muricauda ruestringensis gen. nov., sp. nov., a facultatively anaerobic, appendaged bacterium from German North Sea intertidal sediment. Int J Syst Evol Microbiol 51, 1997-2006.

Cowan, S. T. \& Steel, K. J. (1965). Manual for the Identification of Medical Bacteria. London: Cambridge University Press.

Felsenstein, J. (1981). Evolutionary trees from DNA sequences: a maximum likelihood approach. J Mol Evol 17, 368-376.

Felsenstein, J. (1993). PHYLIP (phylogeny inference package), version 3.5. Department of Genetics, University of Washington, Seattle, USA.

Glöckner, F. O., Fuchs, B. M. \& Amann, R. (1999). Bacterioplankton compositions of lakes and oceans: a first comparison based on fluorescence in situ hybridization. Appl Environ Microbiol 65, 3721-3726.

Johansen, J. E., Nielsen, P. \& Sjøholm, C. (1999). Description of Cellulophaga baltica gen. nov., sp. nov. and Cellulophaga fucicola gen. nov., sp. nov. and reclassification of [Cytophaga] lytica to Cellulophaga lytica gen. nov., comb. nov. Int J Syst Bacteriol 49, 1231-1240.

Jukes, T. H. \& Cantor, C. R. (1969). Evolution of protein molecules. In Mammalian Protein Metabolism, vol. 3, pp. 21-132. Edited by H. N. Munro. New York: Academic Press.

Kirchman, D. L. (2002). The ecology of Cytophaga-Flavobacteria in aquatic environments. FEMS Microbiol Ecol 39, 91-100.

Kluge, A. G. \& Farris, F. S. (1969). Quantitative phyletics and the evolution of anurans. Syst Zool 18, 1-32.

Komagata, K. \& Suzuki, K.-I. (1987). Lipid and cell wall analysis in bacterial systematics. Methods Microbiol 19, 161-207. 
Lanyi, B. (1987). Classical and rapid identification methods for medically important bacteria. Methods Microbiol 19, 1-67.

Leifson, E. (1963). Determination of carbohydrate metabolism of marine bacteria. J Bacteriol 85, 1183-1184.

McCammon, S. A. \& Bowman, J. P. (2000). Taxonomy of Antarctic Flavobacterium species: description of Flavobacterium gillisiae sp. nov., Flavobacterium tegatincola sp. nov., and Flavobacterium xanthum sp. nov., nom. rev. and reclassification of [Flavobacterium] salegens as Salegentibacter salegens gen. nov., comb. nov. Int J Syst Evol Microbiol 50, 1055-1063.

Nakagawa, Y. \& Yamasato, K. (1996). Emendation of the genus Cytophaga and transfer of Cytophaga agarovorans and Cytophaga salmonicolor to Marinilabilia gen. nov.: phylogenetic analysis of the Flavobacterium-Cytophaga complex. Int J Syst Bacteriol 46, 599-603.

Nakagawa, Y., Hamana, K., Sakane, T. \& Yamasato, K. (1997). Reclassification of Cytophaga aprica (Lewin 1969) Reichenbach 1989 in Flammeovirga gen. nov. as Flammeovirga aprica comb. nov. and of Cytophaga diffluens (ex Stanier 1940; emend. Lewin 1969) Reichenbach 1989 in Persicobacter gen. nov. as Persicobacter diffluens comb. nov. Int J Syst Bacteriol 47, 220-223.

Nedashkovskaya, O. I., Suzuki, M., Vysotskii, M. V. \& Mikhailov, V. V. (2003). Reichenbachia agariperforans gen. nov., sp. nov., a novel marine bacterium in the phylum Cytophaga-FlavobacteriumBacteroides. Int J Syst Evol Microbiol 53, 81-85.

Reichenbach, H. (1989). Order I. Cytophagales Leadbetter 1974, $99^{\mathrm{AL}}$. In Bergey's Manual of Systematic Bacteriology, vol. 3, pp. 20112082. Edited by J. T. Staley, M. P. Bryant, N. Pfennig \& J. G. Holt. Baltimore: Williams \& Wilkins.

Reichenbach, H. (1992). The order Cytophagales. In The Prokaryotes, Handbook on the Biology of Bacteria: Ecophysiology, Isolation, Identification, Applications, 2nd edn, pp. 3631-3675. Edited by A. Balows, H. G. Trüper, M. Dworkin, W. Harder \& K. H. Schleifer. New York: Springer.
Saitou, N. \& Nei, M. (1987). The neighbor-joining method: a new method for reconstructing phylogenetic trees. Mol Biol Evol 4, 406-425.

Sakamoto, M., Suzuki, M., Umeda, M., Ishikawa, I. \& Benno, Y. (2002). Reclassification of Bacteroides forsythus (Tanner et al. 1986) as Tannerella forsythensis corrig., gen. nov., comb. nov. Int J Syst Evol Microbiol 52, 841-849.

Sasser, M. (1990). Identification of Bacteria by Gas Chromatography of Cellular Fatty Acids. Newark, DE: MIDI.

Suzuki, M., Nakagawa, Y., Harayama, S. \& Yamamoto, S. (2001). Phylogenetic analysis and taxonomic study of marine Cytophaga-like bacteria: proposal for Tenacibaculum gen. nov. with Tenacibaculum maritimum comb. nov. and Tenacibaculum ovolyticum comb. nov., and description of Tenacibaculum mesophilum sp. nov. and Tenacibaculum amylolyticum sp. nov. Int J Syst Evol Microbiol 51, 1639-1652.

Tamaoka, J. \& Komagata, K. (1984). Determination of DNA base composition by reverse-phase high-performance liquid chromatography. FEMS Microbiol Lett 25, 125-128.

Thompson, J. D., Higgins, D. G. \& Gibson, T. J. (1994). CLUSTAL W: improving the sensitivity of progressive multiple sequence alignment through sequence weighting, position-specific gap penalties and weight matrix choice. Nucleic Acids Res 22, 4673-4680.

Yoon, J.-H., Km, H., Kim, S.-B., Kim, H.-J., Kim, W. Y., Lee, S. T., Goodfellow, M. \& Park, Y.-H. (1996). Identification of Saccharomonospora strains by the use of genomic DNA fragments and rRNA gene probes. Int J Syst Bacteriol 46, 502-505.

Yoon, J.-H., Lee, S. T. \& Park, Y.-H. (1998). Inter- and intraspecific phylogenetic analysis of the genus Nocardioides and related taxa based on 16S rDNA sequences. Int J Syst Bacteriol 48, 187-194.

Yoon, J.-H., Kim, I.-G., Shin, D.-Y., Kang, K. H. \& Park, Y.-H. (2003). Microbulbifer salipaludis sp. nov., a moderate halophile isolated from a Korean salt marsh. Int J Syst Evol Microbiol 53, 53-57. 